\title{
Cobb syndrome (cutaneomeningospinal angiomatosis)
}

\author{
Mehrnaz Ighani, ${ }^{1}$ Albert J Aboulafia ${ }^{2,3}$
}

${ }^{1}$ School of Public Health, University of Maryland at College Park, College Park, Maryland, USA

${ }^{2}$ Director MedStar Baltimore Region Cancer Network, MedStar Franklin Square Hospital, Baltimore, Maryland, USA

${ }^{3}$ Oncology and Orthopaedics, Georgetown University School of Medicine, Washington DC, USA

Correspondence to Miss Mehrnaz Ighani, mehrnazighani@gmail.com

Accepted 14 July 2018

\section{DESCRIPTION}

A 62-year-old woman was referred to the orthopaedic oncology service for evaluation of a bleeding and enlarging soft tissue mass along the right anterior abdominal wall. She had a lifelong history of a cutaneous and subcutaneous vascular malformation, affecting the right lateral chest and right abdomen and extending proximally to involve the mid-thoracic spine. Her medical history was significant for a prior aborted attempted surgical resection of the vascular malformation in 1980 due to intraoperative bleeding. Her history also included L4-L5 laminectomy without fusion for lower extremity weakness without radicular symptoms in 1989 and coil embolisation of a T9 epidural fistula in 2011 to prevent any abnormal vascular flow. Examination of the bilateral lower extremity showed marked steppage gait with bilateral external rotation deformities and bilateral foot drop. Motor examination of the lower extremities revealed muscle power grading of $1 / 5$ extensor hallucis longus bilaterally, 2/5 tibialis anterior bilaterally, 4/5 flexor hallucis longus, 4/5 knee extension bilaterally and knee flexion 4/5 left, 5/5 right. Physical examination also revealed hyperpigmented, raised vascular changes with 'port wine stains' consistent with cutaneous involvement of two haemangiomas; one along the right chest wall $(9 \times 6 \mathrm{~cm})$ and another on the right abdominal wall $(18 \times 12 \mathrm{~cm})$ (figure 1). Both pigmented areas were surrounded by large subcutaneous distended veins. Despite distal neuropathy and myelopathy and prior medical attention, the patient denied being given a diagnosis of Cobb syndrome.

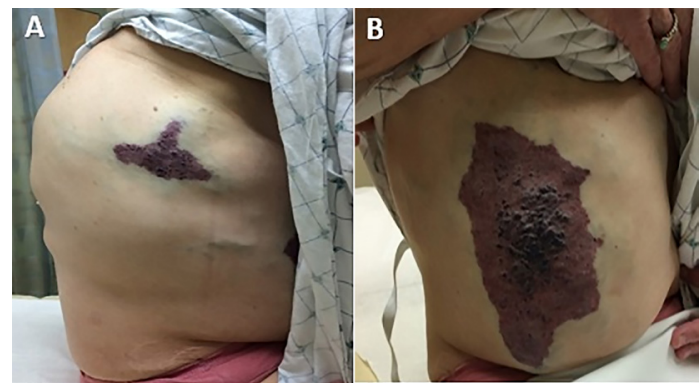

Figure 1 Clinical photographs of the right scapula (A) and abdomen (B) demonstrating large vascular malformations involving skin and subcutaneous tissue.

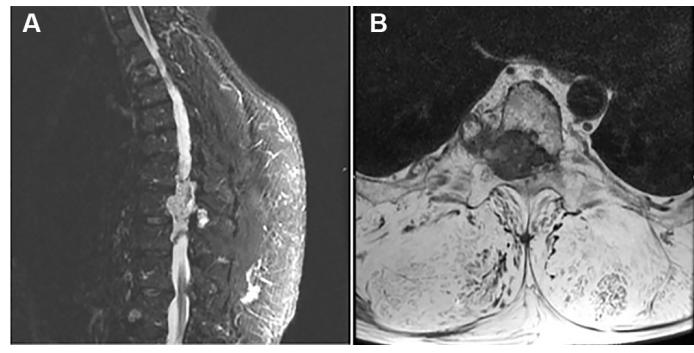

Figure 2 T1-weighted sagittal MRI demonstrating vascular malformation in the right paraspinous soft tissues from $\mathrm{T} 8$ to $\mathrm{T} 12$ with extension into the spinal canal at T8 level (A) and axial MRI demonstrating an infiltrative process involving the posterior vertebral body of the thoracic spine with osseous destruction and encroachment into the epidural space (B).

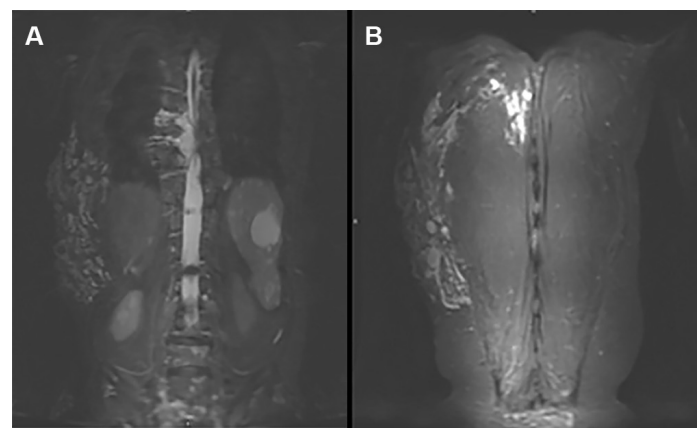

Figure 3 Coronal MRI demonstrating an infiltrative process involving several thoracic vertebrae with epidural extension (A) and diffuse homogeneous lobulated increased signal within the thoracic paraspinous muscles (B).

MRI revealed a large vascular malformation involving the right lateral chest, abdominal wall musculature and right posterior paraspinous musculature that extended into the spinal canal at T8 level with associated vertebral body destruction (figures 2 and 3). The patient was diagnosed with Cobb syndrome, a rare congenital condition characterised with arteriovenous malformations (AVMs) and vascular lesions in the same dermatome with associated spinal angiomas or AVMs. ${ }^{1}$ Treatment considerations centre on preventing or treating neurological symptoms. Treatment options remain ambiguous and have included use of steroids, surgery and endovascular embolisation. Recognition of the associated cutaneous lesions with spinal lesions will allow for prevention and treatment of neurological symptoms. 


\section{Learning points}

If a cutaneous vascular malformation is found to have a metameric distribution on the trunk, a diagnosis of Cobb syndrome should be considered.

- Early diagnosis of Cobb syndrome and assessment of the appropriate treatment reduce permanent consequences such as paraplegia or sensory and motor deficits.

Contributors All authors have substantial contributions towards the conception and design of the work. MI and AJA wrote the manuscript and revised it critically for important intellectual content. All authors approved the final manuscript and agreed to be accountable for all aspects of the work in ensuring that questions related to the accuracy or integrity of any part of the work are appropriately investigated and resolved.

Funding The authors have not declared a specific grant for this research from any funding agency in the public, commercial or not-for-profit sectors.

Competing interests None declared.

Patient consent Obtained.

Provenance and peer review Not commissioned; externally peer reviewed.

\section{REFERENCE}

1 Pal P, Ray S, Chakraborty S, et al. Cobb syndrome: A rare cause of paraplegia. Ann Neurosci 2015;22:191-3.

Copyright 2018 BMJ Publishing Group. All rights reserved. For permission to reuse any of this content visit http://group.bmj.com/group/rights-licensing/permissions.

BMJ Case Report Fellows may re-use this article for personal use and teaching without any further permission.

Become a Fellow of BMJ Case Reports today and you can:

- Submit as many cases as you like

- Enjoy fast sympathetic peer review and rapid publication of accepted articles

- Access all the published articles

- Re-use any of the published material for personal use and teaching without further permission

For information on Institutional Fellowships contact consortiasales@bmjgroup.com

Visit casereports.bmj.com for more articles like this and to become a Fellow 